\title{
Fading with light and greying with age in the fleece of black Australian Polwarth sheep
}

\author{
J.J. LAUVERGNE, Melinda J. BURRILL *, C.H.S. DOLLING ** \\ \& Wendy S. DENNIS *** \\ I.N.R.A., Laboratoire de Génétique factorielle \\ Centre de Recherches zootechniques, $F 78350$ Jouy-en-Josas \\ * Department of Animal Science \\ California State Polytechnic University \\ Pomona, California, 91265 U.S.A. \\ ** Department of Agriculture and Fisheries \\ Box 1671, Adelaide South Australia, 5000 Australia \\ **** Tarndwarncoort \\ Warncoort, Victoria, 3243 Australia
}

\begin{abstract}
Summary
In order to measure the variation of colour related to some external and internal factors, 136 samples of wools were collected in 1979 and 1980 in a flock of black Polwarth sheep kept in the South of Victoria State, in Australia, $38^{\circ}$ latitude South in open air all year long. The genetic formula of these animals at Agouti, Brown and Extension loci was probably $a a, B+B+, E+E+$. The animals were female or wethers, they were rugged for control or non rugged with a coat opaque to visible and U.V. radiations and cut off at $2.5,3.5$ months or one year of wool growth.
\end{abstract}

The colour measurements were made with a colour atlas based on the D.I.N. System.

Except for very rare cases, the growing wool (at the base of the staple) was in the grey scale (which goes from pure white to jet black, without a hue component). With age one could see a greying or silvering of the coloured fleece. This is due to an increase in the number of white fibers and seems independant from light exposure.

Due to exposure to solar radiation there was a fading of the staple to the range of browns. This means the addition of a spectral colour component : the hue, orange in this case. The fading first affects the tip on the staple, about $2 \mathrm{~cm}$ after one year of exposure, and is less intense on the average with lighter greys. In a second step the middle staple is affected, after at least 3.5 months. The middle staple fading is less intense but affects a longer length : about $4 \mathrm{~cm}$ after one year of exposure. The brown shades after fading overlap the shades genetically induced by mutants at the Brown locus B.

There were some rare cases of spontaneous browning from the base of the staple not due to the light of sun but in these animals the hairy parts remained jet black or dark grey.

Greying and fading were mainly restricted to the fleece and result probably from physical properties of the wool fibers deriving from their greater fineness compared to the coarse hair of hairy parts.

In the fleece there was a range of individual variations inside our Polwarth strain for fading and greying which may be explained by genetical differences.

Due to the fading with light the yarns of common mixed coloured wool from spinning mills is in a brown scale : the traditionnal «frieze» («bure» in French).

By rugging the sheep, the discolouration of black and grey fleeces due to light, is easily prevented however it apparently does not have any effect on the progressive greying of fleeces which was seen in some animals. 


\section{I. - Introduction}

Although it comprises only a small fraction of the Australian sheep industry the breeding of coloured sheep in Australia is not negligible; about 50000 head are bred by specialized producers (CURTIS, 1979 ; LAUVERGNE, 1980). The coloured wool is marketed primarily to those interested in handicrafts (spinning, knitting and weaving) and is desirable because it produces naturally coloured yarns which need no dye treatment and because the colours obtained with the natural wool provide a wide variation of shades which can hardly be matched by artificial means.

The wide range of shades among the black pigmented animals which constitue the majority of the coloured population is given primarily by two phenomena : greying and fading.

Greying is an intermixing of white fibers among the coloured ones. Also called silvering the greying may be seen in many breeds where it is congenital or developping with age resulting sometimes in a nearly white fleece in the adult, for example in Karakul breed, see SERRA (1948). This is due in particular by senescence of the melanocyte system, a widely spread behaviour of mammalian pigmentary systems well studied in Man (see FitzPATRICK et al., 1964).

Fading is the discolouration of coloured fibers, from black towards brown, the shades progressively becoming lighter with time. This phenomenon is well known among producers of naturally coloured wool (cf. Serra, 1965 ; NApIER, 1976; MeldRUM, 1979; CuRTIS, 1979). According biochemical experiments the melanin is decolourized by oxydizing agent (remember for example the peroxide blond obtained after $\mathrm{H}^{2} \mathrm{O}^{2}$ applications, NicolaUs, 1968) and one knows that U.V. of solar radiation are oxydizing agents (see also Spearman, 1977).

The papers by Serra (1965) in Portugal and Brooker and Dolling (1965) in Australia were the first attempts to measure these color variations with a color scale. Since, in Australia, the widespread use of rugging the sheep during the last few years provides new experimental facilities to measure fading and greying as the sheepcoat, originally developed to reduce fleece damage due to weathering and contamination from burrs, sand, etc. (LIPSON et al., 1970 ; Aввотт, 1978), does seem to prevent bleaching of pigmented wool (Anonymous, 1979; DENNIS, 1979) hence furnishing control data. The present article is an attempt to use this type of data for a measurement of fading and greying in naturally coloured wool using a color chart.

\section{II. - Material and methods}

\section{The flock and the breed}
A. - The data

The variations in coloured wool were measured in three trials on black coloured Polwarth sheep of the Tarndwarncoort flock belonging to one of us (Wendy DenNis at Warncoort, Victoria). 
The white Polwarth breed was established one hundred years ago in Victoria on three properties (among them Tarndwarncoort) by crossing the Lincoln with the fine Saxon Merino and then backcrossing to the Merino and interbreeding the resultant progeny. The wool quality number is $23 \mu$ on the average, the fleeces weigh an average of $5 \mathrm{~kg}$ (greasy), the staple length ranges from 10 to $14 \mathrm{~cm}$, with an average of $12 \mathrm{~cm}$ (Jeffries et al., 1979 ; see also Polwarth Centenary Souvenir Publication, 1980).

\section{The trials}

In three trials a portion of the sheep were « rugged» with a sheepcoat (Gollin and Company, Ltd. Austral. pat. No. 428078) made of woven pigmented polyethylene which is an adequate filter of both visible and ultra-violet radiation, according to Аввотт (1980) (personal communication); see also the leaflet by Gollin and co (1978).

The coloured animals were black wethers or ewes. Their genetic formula in resp. Agouti, Brown, and Extension loci was probably $a a, B+B+, E+E+$ as all of them had a jet black coat (9-1 or 10-0 in our grey scale, see fig. 1) in the hairy parts. Some with the HST white pattern (head, stockings, tail) did certainly carry the gene $s$ (Adalsteinsson's, 1974 terminology) in the Spotting locus $S$.

In the trials, rugged and non-rugged animals were co-grazed on pasture having some shelter and shade.

The farm of Tarndwarncoort is approximately $100 \mathrm{~km}$ South West $(40 \mathrm{~km}$ due South) or Laveston, the closest weather station in Victoria, which lies at approximately $38^{\circ}$ latitude South. Sunshine data obtained from the Laveston Station (B.F. DANIEL, Bureau of Meteorology, Melbourne ; personal communication) indicate that the long term monthly averages in hours of sunshine in the test area range from a low of 133.3 in May to a high of 258.5 in January. The actual hours recorded for the test period were very close to the long term averages.

Other areas which lie at a similar latitude (North) are Sicily; Tunisia ; Richmond, Virginia ; Saint-Louis, Missouri; Pueblo, Colorado and Sacramento, California.

Trial. I : Twenty purebred coloured Polwarth sheep (ewes and wethers) ranging in age from one to eight years were « rugged» on 8 January 1979. All animals had been shorn previously on October 20,1978. Fifteen animals, shorn at the same time, were left unrugged as controls. Wool samples were taken from all animals from the midback at the next shearing on 22 October 1979 : groups 1 and 2 of table 1 .

Trial II : Thirty-two purebred, coloured Polwarth sheep (ewes and wethers) ranging in age from one to eight years were rugged immediately "off-shear» on 22 October 1979. Six similar animals remained unrugged as controls. Wool samples were taken from the midback and midneck of each animal on 6 February $1980: 3,5$ months later. They gave the groups 3, 4 and 4 bis of table 1 .

Trial III : At the shearing of october 22, 1979, fourteen wether Polwarths were left unrugged and 25 others were rugged. Wool samples were taken from the midback of each animal on October 28,1980, after one year of growth giving the groups 5 and 6 of table 1 . 
TABLE 1

The list of coloured Polwarth samples used in the study

Liste des échantillons de Polwarth colorés utilisés dans l'étude

\begin{tabular}{|c|c|c|c|c|c|c|}
\hline \multirow{2}{*}{$\begin{array}{l}\text { No. } \\
\text { of } \\
\text { Group }\end{array}$} & \multirow{2}{*}{ n } & \multicolumn{3}{|c|}{ Date } & \multirow{2}{*}{ Treatment } & \multirow{2}{*}{$\begin{array}{c}\text { Place } \\
\text { of } \\
\text { sampling }\end{array}$} \\
\hline & & Shearing & Coating & Samp!ing & & \\
\hline 1 & 15 & 20 oct. 78 & no & 22 oct. 79 & $\begin{array}{l}\text { One year wool, un- } \\
\text { coated }\end{array}$ & Back \\
\hline 2 & 20 & 20 oct. 78 & 8 jan. 79 & 22 oct. 79 & $\begin{array}{l}\text { One year wool, coa- } \\
\text { ted at } 2.5 \text { months }\end{array}$ & Back \\
\hline 3 & 6 & 22 oct. 79 & no & 6 feb. 80 & $\begin{array}{l}3.5 \text { months of wool, } \\
\text { uncoated }\end{array}$ & Back \\
\hline 4 & 28 & 22 oct. 79 & 22 oct. 79 & 6 feb. 80 & $\begin{array}{l}3.5 \text { months of wool, } \\
\text { coated }\end{array}$ & Back \\
\hline 4 bis & $28(1)$ & 22 oct. 79 & no & 6 feb. 80 & $\begin{array}{l}3.5 \text { months of wool, } \\
\text { uncoated }\end{array}$ & Neck \\
\hline 5 & 14 & 22 oct. 79 & no & 28 oct. 80 & $\begin{array}{l}\text { One year of wool, } \\
\text { uncoated }\end{array}$ & Back \\
\hline 6 & 25 & 22 oct. 79 & 22 oct. 79 & 28 oct. 80 & $\begin{array}{l}\text { One year of wool, } \\
\text { coated }\end{array}$ & Back \\
\hline
\end{tabular}

(1) The same animals as in group 4, another place of sampling.

\section{B. - The treatment of the wool samples}

Wool samples from the three trials were gently washed with mild wool detergent and luke warm water then rinsed and air dried. When completely dry, they were evaluated for colour by the same person (J.J. LAUvergne) between 10 am and $2 \mathrm{pm}$ near a shaded window in natural light at the latitude of Paris (approximatively $49^{\circ}$ North) in December 1979 and November 1980 for resp. the samples from first and third trial or under similar light conditions in Warncoort, Victoria, in February 1980, for samples from the second trial.

\section{C. - The scale of colour}

Colour measurements were made using a Müller color Atlas (see LAUVERGNE, 1966). Basically with this system - which is derived from the german DIN 
system - each colour is defined in a three dimensional scheme using variables defined in Nickerson (1958) (see also DéribÉré, 1964) :

1) Hue (《teinte» in French) which is that attribute of colours which derive from the spectra and are classed as reds yellows blues, etc. There are 60 hue classifications in the MülLER Atlas. Wool generally falls into the range of 7 through 12 which is the yellow/red range.

2) Value or lightness («valeur» in French) which gives more and more dark colour : from 0 to 10 in the MüLLER's Scale.

3) Saturation of chroma («saturation» in French) which adds more and more brightness : from 0 to 9 in the MüLlER's Scale.

In the Müller Atlas a shade is quoted by a triple number (hue, from 1 to 60 , value from 0 to 10 and saturation from 0 to 9) unless if it is a colour without a hue which is simply in the grey scale (between 0-10 : full white and 10-0 : jet black) and quoted only with two numbers, see in fig. 1 the representation of the value/saturation level.

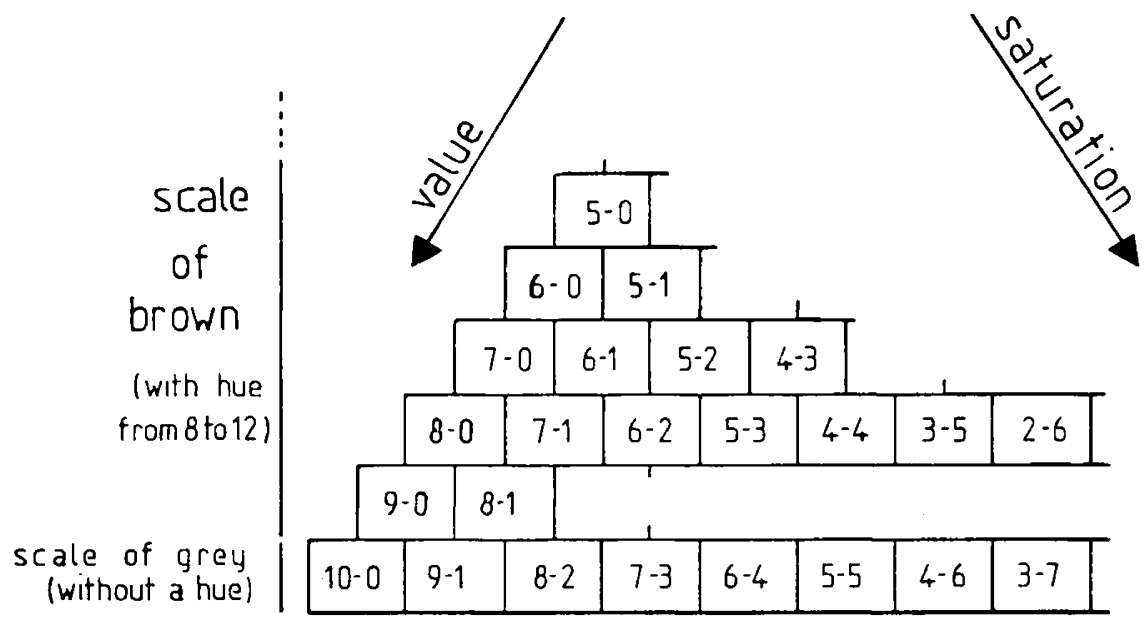

Fig. 1

The value/saturation level of the Müller's atlas showing the scales of brown and grey

Le plan valeur/saturation de l'atlas coloré de Müller montrant les échelles des bruns et des gris

This plotting of value against saturation is similar to the quality/intensity plotting already used by WRIGHT (see for example WRIGHT, 1974) in order to measure the colour of various genotypes in the Guinea Pig. 


\section{III. - Results}

\section{A. - General features}

Staples with multiple banding from region to region across the animal which do exist in Australian flocks and even sometimes in the Tarndwardcoort flock have not been found among our samples.

The staples of our trials were monocoloured, sometimes bicoloured, more rarely tricoloured, with usually a clearcut partition of colour.

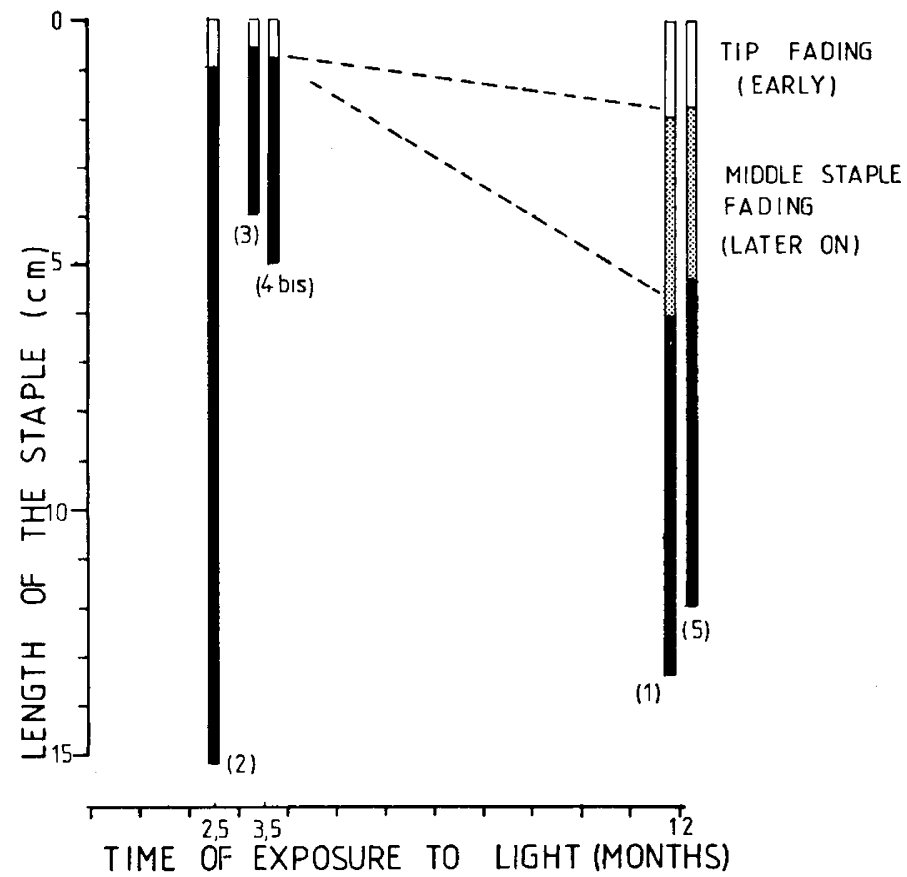

FIG. 2

The process of fading of black coloured Polwarth fleeces due to exposure to light (in brackets the group number)

Le processus de décoloration des toisons colorées en noir de Polwarth sous l'action de la lumière (entre parenthèses les numéros des groupes)

jet black or dark grey noir de jais ou gris foncé

dark brown

brun foncé

light brown

brun clair 
The frequency of various types of pattern : no fading or greying, fading of the tip with or without fading of the middle, fading of the superior half of the staple, greying at the basis of the staple is presented in table 2 .

One must note that (lines 5 and 7) greying may occur in a group in the same time as fading.

\section{B. - Details on fading}

The scale of browns is tridimentional but in our experiment we had practically only one hue, 8 (an orange). An approximative linear scale has been then set up from the darkest to the lightest shades and is used in table 3 and 4 in order to describe the degree of fading according the shade of the wool growing which is always in the linear grey scale, as seen above.

In table 3 which presents data of tip fading 3 types of treatments are distinguished : 2.5 months, 3.5 months and one year exposure : groups 1, 2, 3, 4 bis and 5 .

In table 4 one has pooled middle staple fading in groups 1 and 5 which both were exposed during one full year.

The fading process in these groups is illustrated in figure 2 .

\section{C. - Details on greying}

The evolution of greying with age is presented in two tables : no. 5 and 6 .

In table 5 are pooled groups 1 and 2 : females and wethers cut in 79 and whose ages are given by the year of birth.

In table 6 are pooled groups 3 and 4 of wethers and females cut in Feb. 1980 and whose age is measured in years.

The greying process is illustrated by fig. 3 where the linear scale of grey has been considered from 10 for 10-0 (jet black) to 0 for 0-10 (full white).

\section{IV. - Discussion}

\section{A. - The fading process}

If fading is due to exposure to solar radiation then the coated fleeces must not. be faded at all as we know the rugs are opaque to visible light and to U.V. This is the case for samples 4 and 6 [see table 2 (1)].

(1) With the exception of a small percentage in sample 6, see further on for an explanation. 


\begin{tabular}{|c|c|c|c|c|c|c|c|c|c|}
\hline \multirow{18}{*}{ 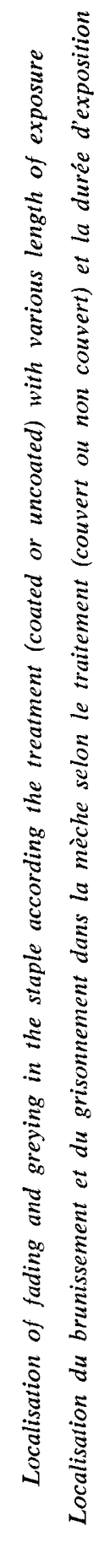 } & \multicolumn{2}{|c|}{ 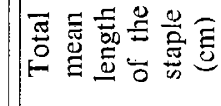 } & \multirow[t]{2}{*}{ 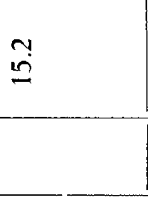 } & \multirow[t]{2}{*}{$\underset{+}{\tilde{+}}$} & \multirow[t]{2}{*}{ 尽 } & \multirow{2}{*}{$\frac{\vec{y}}{\tilde{y}}$} & \multirow{2}{*}{$\begin{array}{l}\stackrel{2}{=} \\
0\end{array}$} & \multirow[t]{2}{*}{$\begin{array}{l}\hat{b} \\
\dot{m}\end{array}$} & \multirow{2}{*}{$\frac{\stackrel{f}{\stackrel{T}{c}}}{\underline{0}}$} \\
\hline & \multirow{3}{*}{ 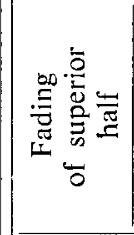 } & $-\overline{\bar{E}}$ & & & & & & & \\
\hline & & $\therefore$ & & & & 0 & 0 & & $\cong$ \\
\hline & & $=$ & & & & 0 & 0 & & $m$ \\
\hline & \multirow{3}{*}{ 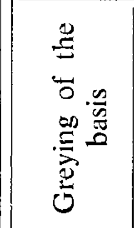 } & $-\widehat{\widehat{\varepsilon}}$ & & & & 0 & $\stackrel{0}{-}$ & & $\overline{i n}$ \\
\hline & & $\therefore$ & & & & 0 & $\underset{⿱}{\pi}$ & & $\simeq$ \\
\hline & & $=$ & & & & 0 & - & & $m$ \\
\hline & \multirow{3}{*}{ 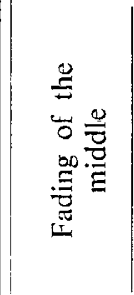 } & $-\widehat{\widehat{\Xi}}$ & 0 & 0 & 0 & $\stackrel{\text { 'b }}{\dot{f}}$ & 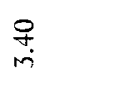 & 0 & 0 \\
\hline & & $\partial^{\circ}$ & 0 & 0 & 0 & $\hat{8}$ & $\stackrel{+}{\stackrel{*}{*}}$ & 0 & 0 \\
\hline & & $=$ & 0 & 0 & 0 & $\stackrel{\circ}{\circ}$ & $\stackrel{9}{0}$ & 0 & 0 \\
\hline & \multirow{3}{*}{ 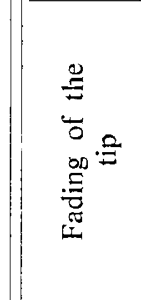 } & - 氖 & $\stackrel{?}{r}$ & \& & $\vec{r}$ & $\vec{s}$ & $\stackrel{+}{-}$ & : & 0 \\
\hline & & $\partial^{\circ}$ & in & \& & 峁 & 8 & 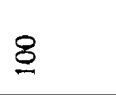 & $\stackrel{\ddot{m}}{\dot{m}}$ & 0 \\
\hline & & $=$ & $=$ & 0 & $\stackrel{\Delta}{N}$ & $\underline{n}$ & \pm & - & 0 \\
\hline & \multirow{3}{*}{ 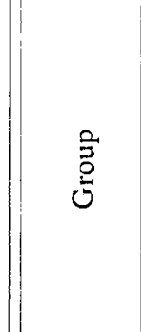 } & 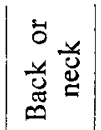 & 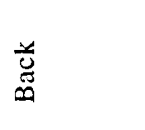 & $\begin{array}{l}\text { यँّ } \\
\cong \pi\end{array}$ & $\begin{array}{l}\breve{u} \\
\ddot{u}\end{array}$ & 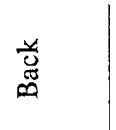 & 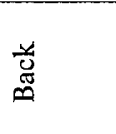 & 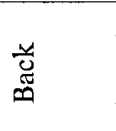 & 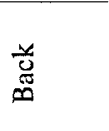 \\
\hline & & $\stackrel{\mathscr{N}}{\stackrel{4}{*}}$ & 요 & 0 & $\stackrel{\infty}{\sim}$ & 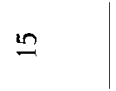 & \pm & $\stackrel{\sim}{\sim}$ & $\stackrel{n}{n}$ \\
\hline & & $\dot{z}$ & $N$ & $m$ & $\frac{n}{2}$ & - & in & + & 0 \\
\hline & & 莺 & 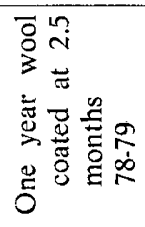 & 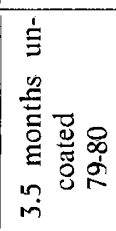 & 竘 & 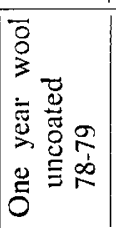 & 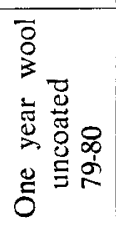 & 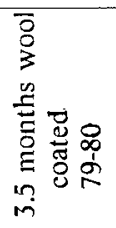 & 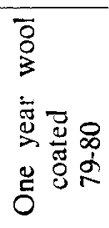 \\
\hline & $\dot{z}$ & & - & N & $m$ & + & in & 0 & r \\
\hline
\end{tabular}




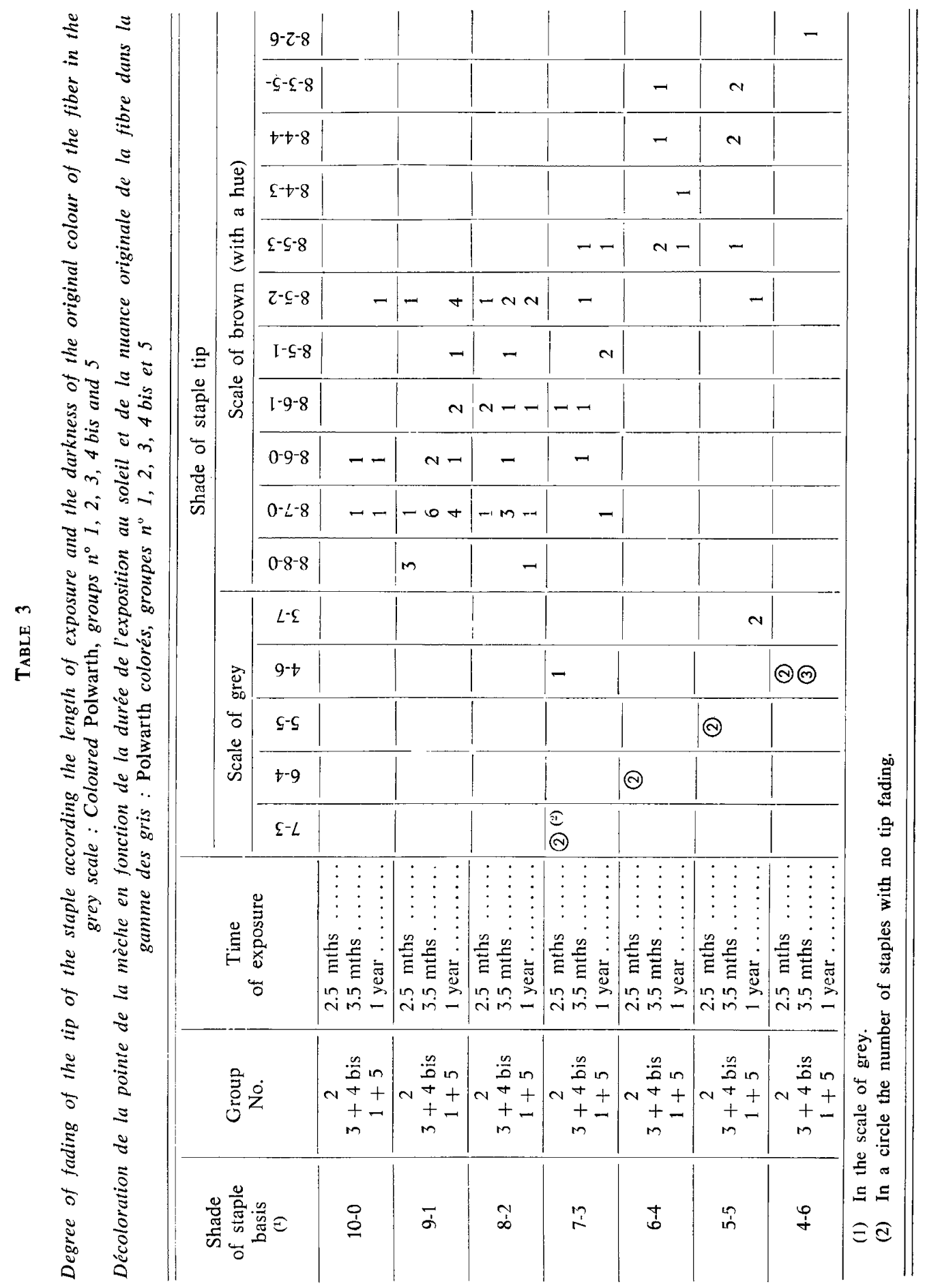




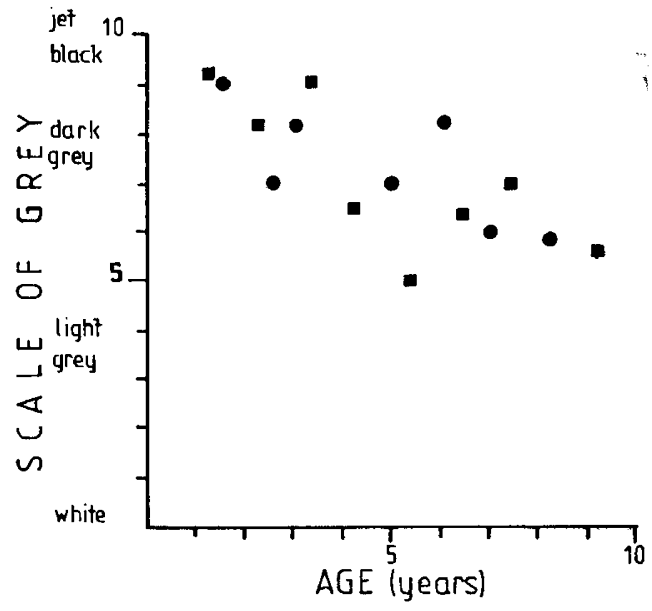

FIG. 3

Greying with age in Polwarth

Le grisonnement avec l'age en race Polwarth

- Groups $n^{\circ} 1$ and 2

Groupes $n^{\circ} 1$ et 2

- Groups $n^{\circ} 3$ and 4

Groupes $n^{\circ} 3$ et 4

TABLE 4

Degree of fading in the middle of the staple according the darkness of the original colour of the fiber in the grey scale, colored Polwarth sample 1 and 5, one year of exposure to daylight (29 animals)

Degré de brunissement du milieu de la mêche fonction de la nuance originale de la fibre dans l'échelle des gris. Polwarth colorés échantillons $n^{0} 1$ et 5 (29 animaux)

\begin{tabular}{|c|c|c|c|c|c|c|c|c|c|c|}
\hline \multirow{3}{*}{$\begin{array}{l}\text { Shade } \\
\text { of non faded } \\
\text { staple basis }\end{array}$} & \multicolumn{10}{|c|}{ Shade of the middle of the staple } \\
\hline & \multicolumn{6}{|c|}{ Scale of grey } & \multicolumn{4}{|c|}{$\begin{array}{l}\text { Scale of brown } \\
\text { (with a hue) }\end{array}$} \\
\hline & $10-0$ & $9-1$ & 8.2 & $7-3$ & $6-4$ & $5-5$ & $8-9.0$ & $8-8-0$ & 8-8-1 & $8-7-i$ \\
\hline$\ldots \ldots \ldots$ & (1) (1) & & & & & & 1 & 1 & & \\
\hline$\ldots \ldots \ldots \ldots$ & & & & & & & 1 & 12. (2) & & \\
\hline$\ldots \ldots \ldots \ldots$ & & & (1) & & & & 1 & 1 & 1 & \\
\hline$\ldots \ldots \ldots \ldots$ & & & & (1) & & & & 1 & 1 & 1 \\
\hline$\ldots \ldots \ldots \ldots$ & & & & & (1) & & & & & 1 \\
\hline $5-5 \ldots \ldots \ldots$ & & & & & & (3) & & & & \\
\hline
\end{tabular}

(1) In a circle the number of staples with no intermediary fading.

(2) Among this group a 10-8-0 shade, very close from 8-8-0 shade. 
TABLE 5

Greying with age, wethered males and females of black Polwarth groups $n^{\circ} 1$ and 2 cut off oct. 1979

Grisonnement avec l'âge, femelles et mâles castrés, groupes de Polwarth noirs $n^{\circ} 1$ et 2, prélevés en octobre 1979

\begin{tabular}{|c|c|c|c|c|c|c|c|c|}
\hline \multirow{2}{*}{ Year of birth } & \multirow{2}{*}{$\begin{array}{c}\text { Age } \\
\text { in years }\end{array}$} & \multicolumn{7}{|c|}{ Shade of the non faded basis of the staple (scale of grey) } \\
\hline & & $10-0$ & $9-1$ & $8-2$ & $7-3$ & 6-4 & $5-5$ & $4-6$ \\
\hline $1978 \ldots \ldots \ldots \ldots$ & 1.20 & 1 & 5 & & & & & \\
\hline $1977 \ldots \ldots \ldots \ldots$ & 2.17 & & 5 & 1 & 3 & & & \\
\hline 1976 (1) $\ldots \ldots \ldots$ & 3.25 & & 2 & & & & & \\
\hline$\ldots \ldots \ldots \ldots$ & 4.16 & & & 3 & & 1 & 1 & 1 \\
\hline 1974 & 5.29 & & & & & 1 & 1 & 1 \\
\hline 1973 & 6.41 & & & & & 1 & & \\
\hline 1972 & 7.41 & & & 1 & & & & \\
\hline 1971 & 8.16 & & & & 1 & & & \\
\hline 1970 & 9.22 & & & & 1 & & 2 & \\
\hline
\end{tabular}

(1) Plus one 12-9-0 sample in the brown scale.

TABLE 6

Greying with age of wethers and females, black Polwarth groups $n^{\circ} 3$ and 4 cut off. feb. 1980

Grisonnement avec l'âge mâles castrés et femelles, groupes de Polwarth noirs $n^{\circ} 3$ et 4 prélevés en février 1980

\begin{tabular}{|c|c|c|c|c|c|c|c|}
\hline \multirow{2}{*}{ Age in year } & \multicolumn{7}{|c|}{ Shade at the non faded basis of the staple (scale of grey) } \\
\hline & $10-0$ & $9-1$ & $8-2$ & $7-3$ & $6-4$ & $5-5$ & $4-6$ \\
\hline $1.5 \ldots \ldots \ldots$ & & 6 & & & & & \\
\hline $2.5 \ldots \ldots \ldots \ldots$ & & & & 2 & & & \\
\hline $3 \ldots \ldots \ldots \ldots$ & & 3 & & & 1 & & \\
\hline $4 \ldots \ldots \ldots \ldots$ & & & & & & & \\
\hline $5 \ldots \ldots \ldots \ldots$ & & & 1 & & 1 & & \\
\hline $6 \ldots \ldots \ldots \ldots$ & & 1 & 3 & & & & \\
\hline $7 \ldots \ldots \ldots \ldots$ & & & 1 & & 1 & 2 & \\
\hline $8-8.5 \ldots \ldots \ldots$ & & 1 & & 3 & 1 & 3 & 2 \\
\hline Total & 0 & 11 & 5 & 5 & 4 & 5 & 2 \\
\hline
\end{tabular}


Moreover this discoloration must be proportional with the time of exposure. This is also the case for sample 3 and 4 bis (3.5 months of exposure) which are less faded than sample 4 and 5 (1 year of exposure) (see figure 2 ).

The fading process involves first the tip of the staple as seen above. It seems proportional in intensity with the degree of greyness of the growing wool (see table 3 ) but, in light grey wool sometimes, this is not the case.

After the tip, the middle of the staple is reached by the process but in a less intense way (table 4) and after a duration which excesses 3.5 months, as we do not see any fading midstaples in our 3.5 months samples (table 2 lines 2 and 3). As we have not sampled between 3.5 months and one year the commencement of this middle staple fading cannot be determined precisely.

The other characteristic of this middle staple fading is to affect a greater length than the tip fading : about twice the length, see table 2, lines 4 and 5 .

There is no precise description of this two step of fading in the earlier literature. In the paper by SERRA (1965), this author has unfortunately mixed measurement of fading and greying and proposed a scale which includes full staples. This, after the various association of shades at the base, middle and tip of the staple makes its use quite difficult. Moreover no reference to a physical measurement of colour is given. Even with these defects the SERrA's article must nevertheless be considered as the pioneer work in the field as the pointed out the necessity of using colour charts.

In the article by Brooker \& Dolling (1965), the Munsell soil color chart was used and the authors said :

"To date no adult sheep has been observed with brown wool growing from the skin. Brown wool found at the distal end of a pigmented staple has invariably been associated with light grey to black wool at the proximal end. »

This fits our present observations well. Nevertheless, these authors said further on that brown fibres have been observed in the birth-coat of black lambs, a rare feature which has been confirmed in checking lambs at Tarndwarncoort and which could explain the "fading 》 of the 3 cases of table 2 line 7 among one year wool, coated animals which, according our views, must not fade : the brown upper zone could be a congenital brown which has disappeared at with age.

These sorts of considerations introduce the more general discussion of brown in sheep. The genetical brown colour induced by the $b$ allele (first identified by ADALSTEINSSON, 1970 and named by homology with other mammals, see SEARLE, 1968) gives shades which have first been measured by Denis et al. (1979) (see also LAUVERGNE \& BoTTEMA, 1979) and which overlap the shades reached by black after fading, as found in the present article.

When there is a light grey to black wool at the proximal end of the staple there is no possible confusion but there still is no explanations for the brown lamb coat described above or the brown adult fleeces of jet black headed animals which have also been seen and measured by some authors of this article (Dolling \& LAUvergne, unpublished data). The question is still open but already it appears that the checking of colour of hairy parts of the body must be done carefully, in order to distinguish 
genetically true brown sheep from genetically black sheep whose fleece has faded to brown.

As one can see in table 2 (lines 4 and 5 in particular) there are variations in the fading ability of fleeces since about 30 p. 100 of the animals had no intermediary fading zone in their back staple. This indicates there is probably a genetic component for fading.

In addition, one of us (M.J. BurRILL) in U.S.A. (but it is of common observation in France also) has had communications with breeders of black animals whose jet back fleeces do not fade, a feature which, in our data, is observed only among grey fleeces.

It was also of common observation in our samples that pratically no fading was seen among hairy zones such as the head, even when fleece was much faded. This may be due to the fineness of the wool fiber which, having a thiner screen of keratin offers less protection against oxydising solar radiation.

Even if fading is apparently rather rare in coarse hairy coat of mammals (in fact we have not found any article devoted to that point) some unpublished observations on the goat (specially in the long hairy strains such as the French Poitevine or Corsican Goat) show that some tip fading may be observed.

\section{B. - The greying process}

The greying in Polwarth is obviously an endogenous developing process with age as one can seen in fig. 3 .

The process seems to be a progressive one but, in some cases, it is quite variable as one can see some staples with a dark grey tip and a light grey base : see table 2 , lines 5 and 7 .

The already quoted Portuguese author SERra (1948) summarized the knowledge on greying known up to that time. In some breeds such as the Karakul the depigmentation with age is quite constant but with variable expressivity, according the strains. This author suggests the possible influence of fineness of wool. A list of possible mendelian factors is given but these must be considered in light of the knowledge of that time.

Since Serra's review, AdALSTEInsson (1970) has shown that at least one mendelian factor, the $A^{g}$ (grey) allele at the $A g o u t i$ locus, may play a major role in greying with age. This factor or a close allele may be responsible for the special colour of Gotland sheep pelt (ADALSTEINSSON et al., 1978).

In our case it is difficult to give a conclusion for the Polwarth. The greying tendency with age is noticeable (see fig. 3) but there is great individual variation : see table 5 line 8 or table 6 line 8 , for example.

A polygenic inheritance could explain these variations in a coloured strain where no selection for grey has yet been done. The genes could combine their action to the general process of greying with age linked with the senescence and known in many species, specially Man (Spearman, 1977). The wool greying quicker than the hair as 
generally observed in our data where the hairy faces remained black or dark grey may be due to the fineness of the wool fiber where the inclusion of melanosomes were more difficult than in much coarser hair, a point already faced by SEkka (see above).

\section{C. - Some practical considerations}

The tip and middle staple fading is responsible for the final shade of yarn spun with uncoated black wool which is never jet black but «frieze 》 ( in French). As a matter of fact, the darkest shade of coloured yarn produced in spinning mills in France (La Noisette, Auzances, Creuse) as well as in Australia (SACSOS) are in the brown scale (12-8-0 and 8-8-0) and not in the grey one (hueless).

By using sheep rugs the coloured wool producers are able to furnish customers with fleeces in the black-grey range of colour.

Coating, a practice already utilized by some coloured wool producers, after the CSRIO trials (see AввотT, 1978) is an advantage for colour control. Our data confirm another already recognized advantage by Аввотт : that of the length of the staple (see in table 2 an increase of about 5 p. 100 of one year coated versus uncoated animals, lines 5 and 7).

\section{D. - Suggested additional research}

One must keep in mind that these data come from a commercial flock with the simplest sampling procedures. This explains why some facets have been only briefly studied.

A comprehensive study of greying with age, following animals year after year and checking the variation in different strains need to be established.

For fading, more data needs to be collected between 3.5 months of exposure and the time when the middle staple fading starts.

For greying, as well as for fading, one needs extended topographical studies, the mid dorsal sampling (with some neck samples) being only a partial description of the phenomenon.

More data also is needed for a comparison between males and females with detailed information obtained in the first period of the life of the animal.

In addition some further research on heritability of fading in all black flocks could be done in order to precise the part of genetical control on fading of melanins.

Of course, the present experiment, which is restricted to the Polwarth breed, needs to be extended to the other coloured breeds. 


\section{V. - Conclusions}

The study presents several weaknesses but describes already the way fading occurs in black pigmented fleeces submitted to natural light : first the tip, then, after at least 3.5 months, the middle staple. For greying the age tendency is clearly demonstrated.

Received for publication in may 1981.

\section{Acknowledgements}

Thanks are due to Dr Aввotr (C.S.I.R.O., Division of Textile Industry, Geelong, Vic.) and Dr DANIEL (Bureau of Meteorology, Melbourne) for having provided indispensible details upon rugging and meteorology.

The paper has been read by Drs Adalsteinsson (Iceland) and Rougeot (France) whose help was appreciated.

\section{Résumé}

\section{Décoloration avec la lumière et grisonnement avec l'âge de la toison de moutons Polwarth noirs en Australie}

Afin de mesurer les variations colorées de la toison au cours de la vie de l'animal et les mettre en relation avec des facteurs endogènes et exogènes, des échantillons de laines ont été prélevés à l'intérieur d'un troupeau Polwarth pigmenté noir dans l'Etat de Victoria en Australie, par $38^{\circ}$ de latitude Sud, en plein air intégral. La formule colorée probable était $a a, B+B+, E+E+$ pour les trois loci Agouti, Brun et Extension. Ces animaux, des femelles ou des mâles castrés, étaient soit nus soit bâchés avec un manteau fait de résine polyéthylène imperméable aux radiations visibles et aux ultra-violets. Cent trente-six prélèvements, groupés en 7 échantillons, ont eu lieu en 1979 et 1980.

La mesure de la couleur s'est faite à l'aide de l'Atlas coloré de Müller basé sur le système allemand D.I.N.

Sauf de très rares cas, la nuance de la mèche colorée était, à la base, dans l'échelle des gris qui va du blanc pur au noir de jais, sans composante spectrale. On notait un grisonnement (ou argenture) avec l'âge, avec beaucoup de variations interindividuelles, qui était dû à une augmentation du nombre des fibres blanches. Ce grisonnement semble indépendant de l'exposition à la lumière.

Causée par l'exposition à la lumière solaire, il y avait une décoloration de la mèche dans l'échelle des bruns, c'est-à-dire avec une composante spectrale dans les oranges. La décoloration affectait tout d'abord la pointe de la mèche $(2 \mathrm{~cm}$ environ au bout d'un an d'exposition), puis le milieu de la mèche mais seulement quand l'exposition était supérieure à au moins 3 mois et demi. Cette décoloration était moins intense mais affectait une longueur plus grande : environ $4 \mathrm{~cm}$ après un an d'exposition. La décoloration était variable selon les individus et absente parfois sur des mèches gris clair.

Ces nuances dans le brun recouvrent les nuances brun chocolat observées chez les animaux génétiquement bruns $(b b)$.

Quelques rares cas de brunissement spontané depuis la base ont été notés chez des animaux dont les parties poilues (têtes et pattes) restaient colorées en noir ou gris foncé. 
La décoloration et le grisonnement sont principalement limités à la toison chez le Polwarth. Cela peut résulter des propriétés physiques de la fibre de laine beaucoup plus fine que le poil qui recouvre la tête et les pattes.

On constate des variations individuelles assez importantes tant pour la décoloration que pour le grisonnement à durée d'exposition ou âge égaux. Au moins partiellement, ces différences peuvent avoir une base héréditaire.

En raison de la décoloration due à la lumière, les écheveaux de laine colorée commune mélangée en provenance des filatures sont dans l'échelle des bruns : ils donnaient traditionnellement les étoffes dites «de bure», le mot «bure» ou «burel» rappelant leur couleur brun foncé.

L'utilisation de manteaux sur les moutons permet d'obtenir facilement des toisons non décolorées par la lumière mais re permet apparemment pas de contrôler le grisonnement.

\section{References}

Аввотт G.M., 1978. The Benefits and Economics of the Rugging of Sheep with Polyolefin Fabrics. C.S.I.R.O., Division of Textile Industry, Report $\mathrm{n}^{\circ} \mathrm{G} 36,6 \mathrm{p}$.

Adalsteinsson S., 1970. Colour inheritance in Icelandic Sheep and relation between colour, fertility and fertilization. J. agr. Res. Icel., 2, 3-135.

Adalsteinsson S., 1974. Colour inheritance in farm animals and its application in Selection. Irst World Congr. Genet. appl. Livest. prod., 1, 29-37.

Adalsteinsson S., Lauvercne J.J., Boyazoglu J.G., Ryder M.L., 1978. A possible genetic interpretation of the colour variants in the fleece of the Gotland and Goth sheep. Ann. Génét. Sél. anim., 10, 329-342.

Anonymous, 1979. Rugging sheep to improve wool quality. C.S.I.R.O., Rural Research (103), $12-15$.

Brooker M.G., Dolling C.H.S., 1965. Pigmentation of sheep. I. Inheritance of pigmented wool in the Merino. Austr. J. agric. Res., 16, 219-228.

CuRTIS C., 1979. The black and coloured wool industry in Australia. The Australian Wool Corporation, Melbourne.

Denis B., Lauvercne J.-J. Théret M., 1978. Un variant clair du Mouflon Corsico-Sarde (Ovis musimon) dû à un allèle au locus B (Brun). Ann. Génét. Sél. anim., 10, 507515.

Dennis Wendy S., 1979. Sheepcoats for Black and Coloured Polwarth Sheep. In: Breeding Coloured Shecp and using coloured wool. S.A.C.S.O.S., Adelaide, S.A., Australia.

DÉribÉrÉ M., 1964. La couleur. P.U.F., Paris.

FitzPatrick T.B., Szabo G., Mitchell Ruth E., 1964. Age change in the human melanocyte system. In : W. Montagna, Adv. Biol. Skin, vol. 6, Aging, Pergamon, Oxford, London, $35-50$.

Gollin and Co, 1978. Sheepcoats : a guide to Fittings and Prices. A leaflet of 2 pages, Austratia.

Jeffries B.C., Liebelt M.A., Williams R.D., 1979. Livestock from South Australia : Sheep, Dairy and Beef Breeds. Department of Agriculture and Fisheries of South Australia, Adelaide S.A., Australia.

Lauvergne J.-J., 1966. Contribution à l'étude de l'hérédité de la couleur du pelage chez les bovins domestiques. Thèse Fac. Sci. Univ. Paris (3 Cycle).

Lauvergne J.-J., 1980. Le petit élevage de moutons colorés en Australie. Ethnozootechnie, (26), 65-71.

LAUvergne J.-J., BotTema A., 1979. Variants colorés chez le mouton Néerlandais des Landes de Bruyère (Heideschaap). Ann. Génét. Sél. anim., 11, 1-6. 
Lipson M., Ellingworth J.S., Sinclair J.F., 1970. Effect of Sheep-Rugging on Fleece Properties and Processing of Wool. Text. Inst. Ind., 8, 100-102.

Meldrum J., 1979. So you want to breed black sheep. Black and Coloured Sheep Breeders' Association : Information leaflet $\mathrm{n}^{\circ}$ 2, Victoria, Australia.

Müller, Grosser Mobiler Schweizer Colour Atlas 2541. Chromos Verlag, Winterthur, Schweiz.

NAPIER K., 1976. Breeding of black sheep. J. Agric. Victoria, 74, 208-210.

Nickerson D., 1958. Colour measurement and its application to the grading of agricultural products. U.S.D.A., misc. publ. 80.

Nicolaus R.A., 1968. Melanins. Hermann, Paris.

Polwarth Centenary Souvenir Publication, 1980. Insert in Stock and Land, Australia, July 3, $28 \mathrm{p}$.

Searle A.G., 1968. Comparative Genetics of Coat Colour in Mammals. Logos Press, Academic Press, London, New York,

Serra J.-A., 1948. Génétique du mouton. Publ. Junta Pecuar, Lisboa (Ser. A), n 1, 14-75.

Serra J.-A., 1965. Echelles de couleur des laines et des yeux chez le mouton. Publ. Iunta Pecuar, Lisboa, Ser. A, $\mathrm{n}^{\circ} 9$.

SPEarman R.I.C., 1977. The Genetics of Hair Growth and Coloration. In : A. Jarrett, The Physiology and Pathophysiology of the skin, vol. 4 : The Hair Follicule, (43), 1457-1494 (See in particular pp. 1481-1482). 